\title{
Organic Solvent-tolerant Lipase from Pseudomonas sp. BCNU 154
}

\author{
Hye Jung Choi', Min Jung Hwang ${ }^{1}$, Jeoung-Yoon $\mathrm{SeO}^{2}$ and Woo Hong Joo ${ }^{1}$ * \\ ${ }^{1}$ Department of Biology and Interdisciplinary Program for Biotechnology, Changwon National University, Changwon 641-773, Korea \\ ${ }^{2}$ Department of Environmental Engineering Changwon National University, Changwon 641-773, Korea
}

Received January 23, 2013 / Revised September 30, 2013 / Accepted October 22, 2013

\begin{abstract}
An organic solvent-tolerant lipase of Pseudomonas sp. BCNU 154 that was isolated from wastewater in the industrial complex region had optimal activity at $37^{\circ} \mathrm{C}$ and $\mathrm{pH}$. This crude extracellular lipase from BCNU 154 exhibited maximum stability in toluene, retaining about $6.01 \mathrm{U} / \mathrm{ml}(117.53 \%)$ activity for $2 \mathrm{~h} . \mathrm{Ca}^{2+}, \mathrm{Mg}^{2+}, \mathrm{NH}_{4}{ }^{+}$, and $\mathrm{Na}^{+}$ions and triton $\mathrm{X}-100$ activated the enzymes, whereas $\mathrm{Ba}^{2+}, \mathrm{Hg}^{2+}$, and $\mathrm{Zn}^{2+}$ ions inhibited their activity. Pseudomonas sp. BCNU 154 lipase revealed stable activity comparable to that of the commercial immobilized Novozym 435. Thus, this organic solvent-tolerant lipase could have potential as a whole cell biocatalyst in industrial chemical processes without the use of immobilization.
\end{abstract}

Key words : Lipase stability, organic solvent tolerant lipase, Pseudomonas sp., Pseudomonas sp. BCNU 154

\section{서 론}

리파아제는 지질을 분해하여 지방산과 글리세롤을 만드는 지질 가수분해 효소로, 반응조건에 따라 에스테르화합물의 가 수분해뿐만 아니라 이들의 합성반응 및 트랜스에스테르화 반 응 등 다양한 화학반응을 촉매할 수 있다. 리파아제는 높은 위치특이성, 기질특이성 및 입체특이성 등 유용한 반응특성을 가지고 있으며[12], 화학적 촉매 공정에서 발생하는 산업폐수 및 부산물이 적고, 상대적으로 낮은 온도에서 반응이 일어나 므로 에너지 측면에서도 많은 이점이 있어 산업적으로 광범위 하게 활용되고 있는 추세이다[1, 20]. 그러나 효소의 높은 단가 로 제한적으로 사용된다는 점[3], 공정과정에서 안정성과 효소 활성이 낮아지는 점 등 효율성이 떨어지는 단점이 있다. 이에 따라 고정화, 생화학적 수식, 화합물의 첨가 및 단백질공학 기 법 등으로 효소의 안정성을 증가시켜 사용하고 있으며 $[2,10$, 11], 특히 고정화 기술이 산업적 공정에 많이 적용되고 있다. 한편 유기용매 내성 미생물이 생산하는 리파아제는 넓은 범위의 온도와 $\mathrm{pH}$ 조건에서도 안정하며, 효소활성이 뛰어날 뿐만 아니라 수계 조건에서 불가능한 aminolysis, esterification, thiotransesterification, transesterification, oximolysis의 반응을 촉매하는 등 미수계 및 소수계에서의 반응성이 뛰어나기 때문에 정밀화학산업에 많은 이점을 제공한다고 보

\footnotetext{
*Corresponding author

Tel : +82-55-213-3453, Fax : +82-55-213-3459

E-mail : whjoo@changwon.ac.kr

This is an Open-Access article distributed under the terms of the Creative Commons Attribution Non-Commercial License (http://creativecommons.org/licenses/by-nc/3.0) which permits unrestricted non-commercial use, distribution, and reproduction in any medium, provided the original work is properly cited.
}

고되고 있다 $[5,6,17]$.

본 연구에서는 리파아제를 생산하는 유기용매 내성

Pseudomonas sp. BCNU 154 균주의 조효소액으로 온도, 유기 용매 및 금속이온 등 여러가지 환경요인 하에서 효소의 안정 성을 검토함으로써 산업공정에서 보다 경제적이면서 효율적 인 whole cell 리파아제로서의 이용 가능성에 대해 조사하여 보고하고자 한다.

\section{재료 및 방법}

\section{유기용매 내성 세균 분리 및 특성조사}

울산과 안산공단 지역에서 채취한 폐수 및 토양 시료 $1 \mathrm{~g}$ 을 $100 \mathrm{ml}$ 의 nutrient broth (NB)와 Luria-Bertani (LB) broth 배지 에 접종 후 $10 \%(\mathrm{v} / \mathrm{v}) n$-hexane을 첨가하여 $27^{\circ} \mathrm{C}$ 에서 7 일간 농화배양을 실시하였다. $n$ Hexane에 내성을 가진 균주 배양 액 $1 \mathrm{ml}$ 은 $100 \mathrm{ml}$ 의 신선한 LB broth에 재접종하였고 $10 \%$ toluene을 첨가하여 $27^{\circ} \mathrm{C}$ 와 $37^{\circ} \mathrm{C}$ 에서 각각 배양한 뒤, 유기용 매 내성세균을 순수분리하였다. 분리된 균주는 LB agar 배지 에 획선도말한 뒤 toluene을 overlay하여 $37^{\circ} \mathrm{C}$ 에서 3 일 배양하 였고, 최종적으로 toluene에 내성이 뛰어난 균주를 선별하였 다. 선별균주의 생리생화학적 특성과 $16 \mathrm{~S}$ 리보좀 RNA에 기초 한 유연관계는 상법에 준하여 조사하였다.

\section{리파아제 생성조사 및 조효소액 조제}

내성균주의 리파아제 생성여부와 생성정도는 기질로서 $1 \%$ $(\mathrm{w} / \mathrm{v})$ tributyrin $(\mathrm{C} 8)$ 을 $\mathrm{LB}$ agar에 첨가하여 $37^{\circ} \mathrm{C}$ 에서 24-48 시간 배양 후 투명환을 관찰함으로써 확인하였다. 선별된 균 주는 전배양한 후 $\mathrm{LB}$ broth 배지에 접종하고 $37^{\circ} \mathrm{C}$ 에서 24 시간 진탕 본배양하였으며, 배양액은 $10,000 \times g, 15$ 분간 원심분리 
한 후, 상등액을 membrane filter $(0.22 \mu \mathrm{m})$ 로 필터한 후 조효 소액으로서 사용하였다[4].

\section{리파아제 활성 측정}

균주가 생산하는 리파아제의 활성은 조효소액 $100 \mu \mathrm{l}$ 에 50 $\mathrm{mM}$ 의 p-nitrophenyl palmitate (pNPP) $10 \mu \mathrm{l}, 0.5 \%$ Triton $X-100$ 과 $0.15 \mathrm{M} \mathrm{NaCl}$ 이 첨가된 $0.1 \mathrm{M}$ 의 Tris- $\mathrm{HCl}(\mathrm{pH}$ 8) 900 $\mu \mathrm{l}$ 를 혼합하여 $37^{\circ} \mathrm{C}$ 에서 5 분간 반응시킨 후 $410 \mathrm{~nm}$ 에서 흡광 도를 측정하였으며[19], 양성대조구로 고정화 효소인 Novozym 435 를 $1 \mathrm{mg} / \mathrm{ml}$ 농도로 조제하여 사용하였다. $p \mathrm{NPP}$ 에서 1 분 동안 $1 \mu \mathrm{mol}$ 의 pnitrophenol $(\mathrm{pNP})$ 을 생산하는데 관여하는 효소의 양을 1 unit로 하여 효소활성을 계산하였다[9].

\section{$\mathrm{pH}$ 및 온도에 대한 안정성 조사}

$\mathrm{pH}$ 에 대한 안정성을 조사하기 위해 $0.1 \mathrm{M}$ sodium acetate ( $\mathrm{pH} 4-5), 0.1 \mathrm{M}$ potassium phosphate ( $\mathrm{pH}$ 6-7), 그리고 0.1 $\mathrm{M}$ Tris- $\mathrm{HCl}$ buffer ( $\mathrm{pH}$ 8-10)을 조제하여 다양한 $\mathrm{pH}$ 범위에서 30 분간 반응시킨 후 $410 \mathrm{~nm}$ 에서 효소의 잔존 활성을 측정하였
고, 온도에 대한 안정성 조사는 $30-70^{\circ} \mathrm{C}$ 의 다양한 온도 조건에 서 $0.1 \mathrm{M}$ Tris- $\mathrm{HCl}(\mathrm{pH}$ ) 을 사용하여 30분간 효소반응을 실시 하였다.

\section{다양한 유기용매 및 금속이온에 대한 안정성 조사}

유기용매에 대한 효소의 안정성은 조효소액 $3 \mathrm{ml}$ 에 $25 \%$ (v/v) 농도의 benzene, toluene, xylene 및 $n$-hexane 등 9종의 유기용매 $1 \mathrm{ml}$ 을 첨가하여 $37^{\circ} \mathrm{C}$ 에서 $150 \mathrm{rpm}$ 으로 2시간 반응 시킨 후 잔존 효소활성을 확인함으로써 조사하였다[13]. 또한 다양한 금속이온 등의 효소활성에 미치는 영향을 조사하기 위해 조효소액에 $1 \mathrm{mM}$ 의 각종 인자를 첨가하고 $37^{\circ} \mathrm{C}$ 에서 1 시 간 반응시킨 뒤 기질을 첨가하고 5 분간 반응시킨 후 잔존 효소 활성을 측정하였다[7].

\section{결과 및 고찰}

리파아제를 생성하는 유기용매 내성 세균

Pseudomonas sp. BCNU 154는 유기용매에 대한 내성이 뛰

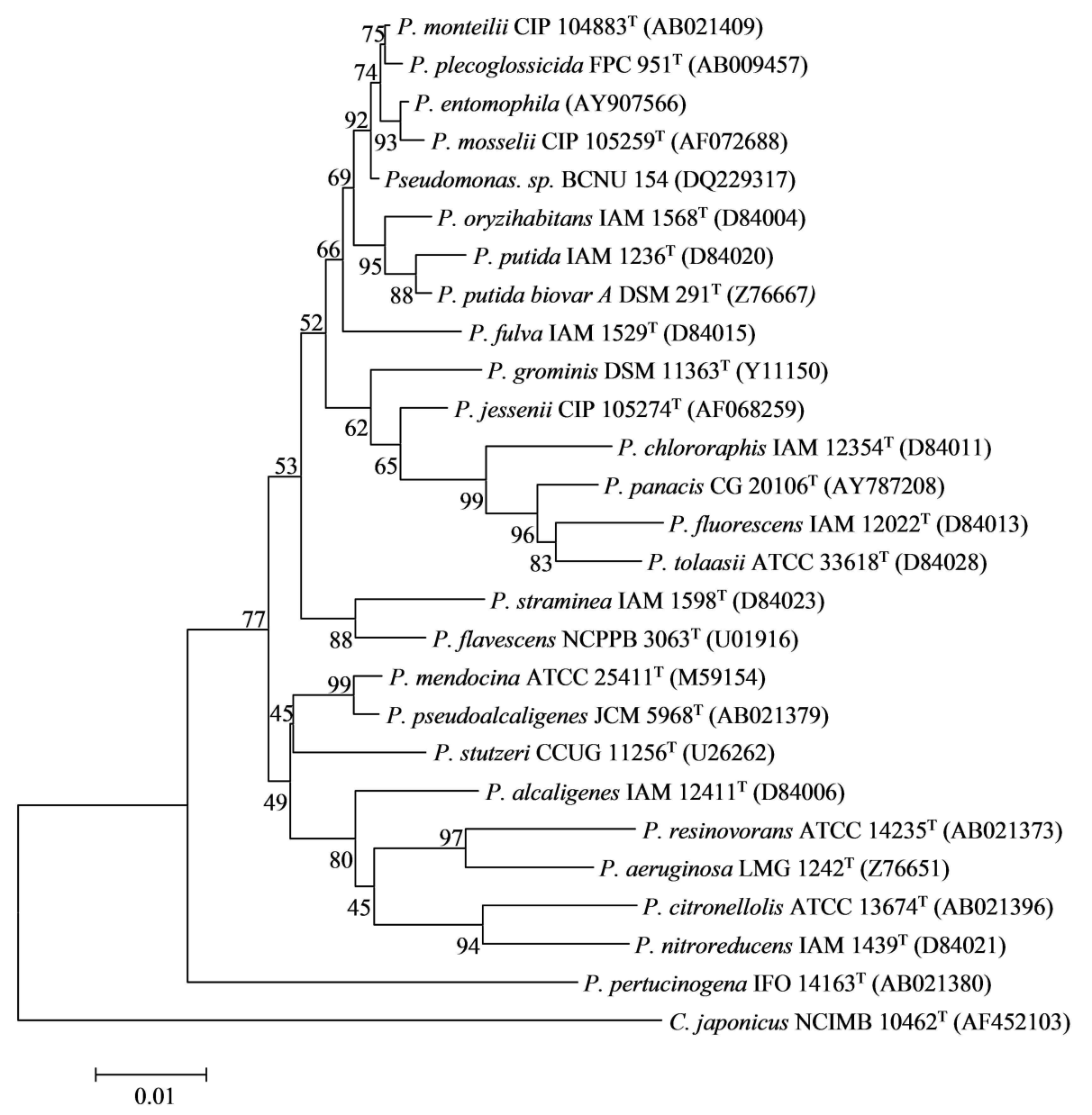

Fig. 1. A phylogenetic tree based on the $16 \mathrm{~S}$ rDNA sequences of the organic solvent-tolerant Pseudomonas sp. BCNU 154 and closely related species. GenBank accession numbers are shown in parentheses. Bootstrap values expressed as a percentage of 1000 replications were given at the branching points. The scale bar represents $1 \%$ sequence dissimilarity. 


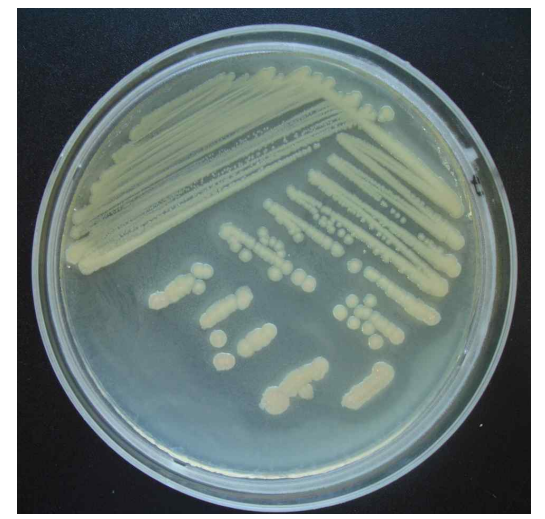

Fig. 2. Lipase activity shown by the clear zones formed around Pseudomonas sp. BCNU 154 colonies.

어난 균주로 toluene을 첨가한 LB agar 배지에서 toluene 분해 산물로 추정되는 노란색(unpublished data) 물질을 생성하며 잘 증식함이 확인되었다. 이 균주는 생리생화학적 성질과 $16 \mathrm{~S}$ 리보좀 염기서열을 기초로 한 계통관계에서 Pseudomanas puti$d a$ 근연종임이 확인되었으며(Fig. 1), tributyrin이 첨가된 배지 에서 콜로니 주변에 투명환을 형성함으로써 리파아제를 생산 함이 확인되었다(Fig. 2).

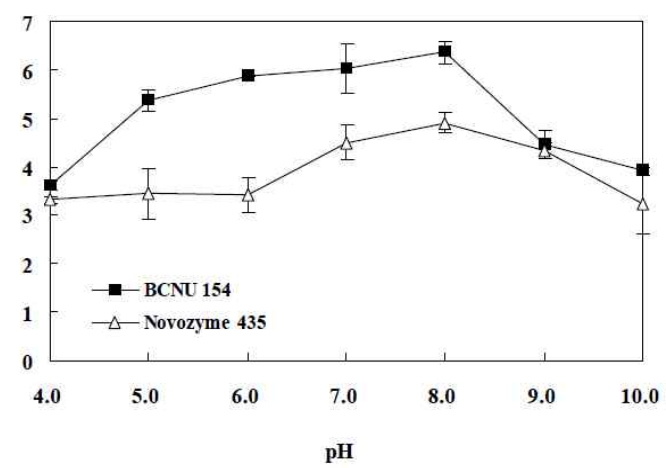

Fig. 3. Effect of $\mathrm{pH}$ on the lipase activity and stability. The stability was measured after incubation at $37^{\circ} \mathrm{C}$ for $30 \mathrm{~min}$ with the following buffers; $0.1 \mathrm{M}$ sodium acetate $(\mathrm{pH} 4-5), 0.1 \mathrm{M}$ potassium phosphate ( $\mathrm{pH}$ 6-7), and $0.1 \mathrm{M}$ Tris- $\mathrm{HCl}(\mathrm{pH}$ 8-10). The remaining activity at $\mathrm{pH} 8(6.4 \mathrm{U} / \mathrm{ml})$ was taken as $100 \%$. All measurements were repeated three times.
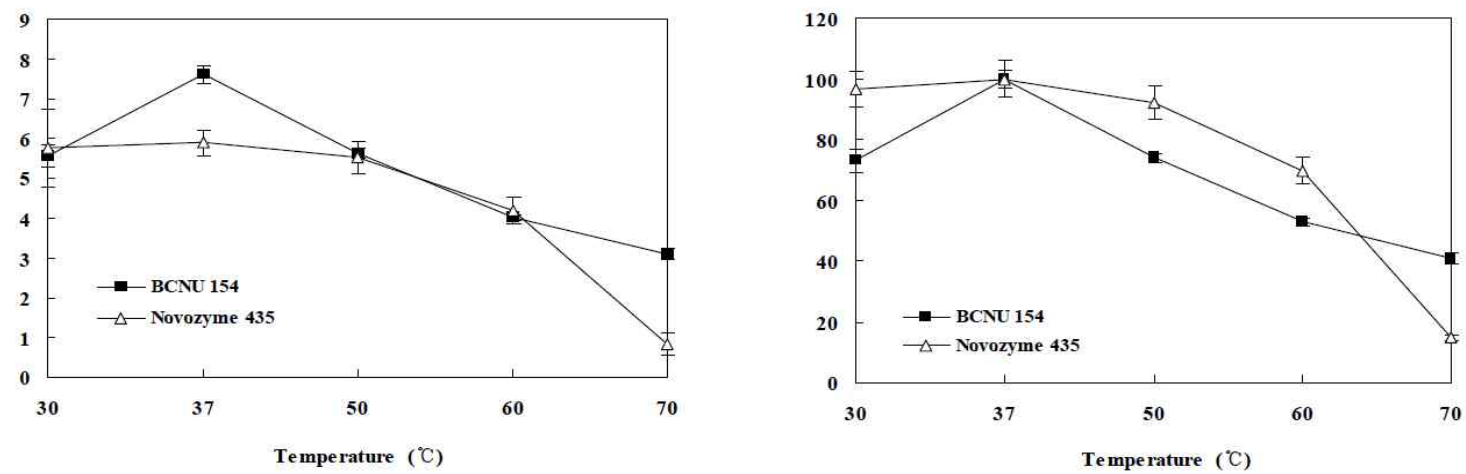

Fig. 4. Effect of temperature on the lipase activity and stability. The diluted cell-free supernatant was incubated with the substrate at different temperatures for $30 \mathrm{~min}$ in $0.1 \mathrm{M}$ Tris- $\mathrm{HCl}$ buffer $(\mathrm{pH} 8)$. The remaining activity $(7.23 \mathrm{U} / \mathrm{ml})$ at $37^{\circ} \mathrm{C}$ was set as $100 \%$. All measurements were repeated three times. 


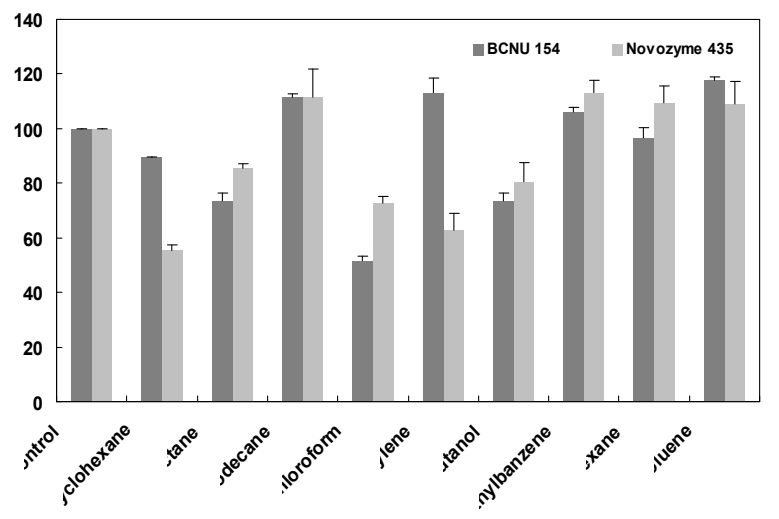

Fig. 5. Effects of various organic solvents on the lipase stability. Lipase stability was assayed by measuring the residual activity after incubation of enzyme $(3 \mathrm{ml})$ in the presence of various organic solvents $(1 \mathrm{ml} ; 25 \% \mathrm{v} / \mathrm{v})$ in $0.1 \mathrm{M}$ Tris-HCl buffer ( $\mathrm{pH} 8.0)$ for $2 \mathrm{~h}$. Error bars represent the standard deviation calculated from at least three independent experiments.

Table 1. Effect of various metal ions and detergents on the lipase activity and stability

\begin{tabular}{lc}
\hline Metal ions/Detergents & Relative activity $(\%)$ \\
\hline None & 100 \\
$\mathrm{CaCl}_{2}$ & $120.82 \pm 2.88$ \\
$\mathrm{CuCl}_{2}$ & $67.38 \pm 0.98$ \\
$\mathrm{MgSO}_{4}$ & $114.90 \pm 2.57$ \\
$\mathrm{BaCl}_{2}$ & $47.42 \pm 1.09$ \\
$\mathrm{HgCl}_{2}$ & $57.01 \pm 2.35$ \\
$\mathrm{NiCl}_{2}$ & $82.34 \pm 3.27$ \\
$\mathrm{ZnSO}_{4}$ & $61.98 \pm 3.35$ \\
$\mathrm{MnCl}_{2}$ & $96.12 \pm 2.29$ \\
$\mathrm{KCl}_{\mathrm{NH}} \mathrm{Cl}$ & $87.80 \pm 2.18$ \\
$\mathrm{NaCl}$ & $126.46 \pm 1.20$ \\
$\mathrm{SDS}$ & $125.21 \pm 4.29$ \\
EDTA & $77.02 \pm 1.95$ \\
Triton x-100 & $69.81 \pm 1.78$ \\
Tween 80 & $106.64 \pm 1.26$ \\
Tween 100 & $101.98 \pm 3.65$ \\
\hline
\end{tabular}

흡착되어 있으며, 바이오디젤 합성반응 등 산업적으로 많이 사용되는 효소로[8], BCNU 154 균주의 조효소액과 다양한 조 건에서 상호 비교 검토함으로써 고정화하지 않고도 산업적으 로 이용될 수 있는지에 대한 가능성을 조사하기 위해 본 실험 에서 양성 대조군으로 사용하였다. 그 결과, $\mathrm{pH}$ 와 온도 안정성 에서 BCNU 154 리파아제는 고정화 효소와 큰 차이가 없음이 확인되었다.

\section{리파아제의 유기용매 및 금속이온 안정성}

고농도(25\%)의 다양한 유기용매에 대한 효소 안정성은 tol- uene, dodecane, xylene, 및 ethylbenzene과 같은 water-immiscible 용매를 첨가했을 때 용매를 넣지 않은 대조군에 비해 각각 $117 \%, 111 \%, 113 \%$ 그리고 $106 \%$ 로 리파아제의 안정성이 증가하였다. 특히 xylene과 cyclohexane 첨가시 Novozym 435 는 안정성이 현저히 감소하는 반면에 BCNU 154는 효소 안정 성이 오히려 증가하거나 $89 \%$ 이상으로 유지되어, 다양한 유기 용매하에서 효소 안정성이 유지되는 것으로 조사되었다(Fig. 5).

Pseudomonas sp. LST-03이 생산하는 리파아제는 BCNU 154 와 유사하게 water-immiscible 용매하에서 효소의 안정성이 있음을 보고되어 있는[13] 반면에, Pseudomonas sp. AG-8에서 는 $20 \%$ 농도의 ethanol과 methanol 등 water-miscible 용매 존재하에서 효소 안정성이 증가함이 보고되었다[16]. 또한 Pseudomonas sp. S5는 30분 처리시 benzene, chloroform, cyclohexane 및 $n$ hexane 존재하에서 높은 안정성이 나타났으나 2시간 처리시에는 1-pentanol, 1-octanol 및 cyclohexane에서 안정성이 떨어지는 것으로 보고되었다[14]. 이에 비해 $\mathrm{BCNU}$ 154 가 생산하는 리파아제는 2시간 처리시에도 chloroform과 $n$-butanol을 제외하고는 대부분 효소 안정성이 증가하거나 유 기용매 존재에 크게 영향을 받지 않는 것으로 확인되어 미수계 반응을 요하는 산업공정에 응용될 수 있을 것으로 판단된다.

또한 다양한 금속이온, 킬레이트제 및 계면활성제를 첨가하 여 효소 안정성을 조사한 결과 $\mathrm{Ca}^{2+}, \mathrm{Mg}^{2+}, \mathrm{NH}_{4}{ }^{+}, \mathrm{Na}^{+}$, triton X-100, tween 80 및 tween 100을 첨가했을 때 리파아제 효소 안정성은 101-126\%로 증가하였다. 반면에 $\mathrm{Cu}^{2+}, \mathrm{Ba}^{2+}, \mathrm{Hg}^{2+}$, $\mathrm{Zn}^{2+}$ 및 $\mathrm{EDTA}$ 는 효소의 안정성을 $30 \%$ 이상 저해하는 것으로 조사되었다(Table 1). Pseudomonas sp. S5 [14], Pseudomonas sp. AG-8 [16] 및 Pseudomonas sp. TK-3가 생산하는 리파아제는 $\mathrm{Ca}^{2+}$ 과 $\mathrm{Mg}^{2+}$ 존재하에 안정성이 증가되었으며, $\mathrm{Cu}^{2+}$ 와 $\mathrm{Zn}^{2+}$ 등의 전이 금속이온에서는 강하게 저해받는 것으로 나타났다 [18]. BCNU 154가 생산하는 리파아제는 상기 균주들에 비해 다양한 알칼리 및 알칼리토금속 존재하에서도 효소 안정성이 증가함으로써 구조적으로도 보다 안정적인 것으로 판단된다.

다양한 산업공정에서 효소 촉매방법을 보다 효율적으로 이 용하기 위해서는 순수 정제된 리파아제를 사용하는 것보다 whole cell 자체를 사용하는 것이 경제적인 측면에서 더 바람 직하며[3], 효소 자체의 안정성 및 활성이 유지된다면 추가 고 정화 비용을 들이지 않고도 안정성과 반응성을 확보할 수 있 어 여러 산업분야에서 광범위하게 이용될 수 있을 것이다. 따 라서 Pseudomanas sp. BCNU 154 균주가 생산하는 리파아제는 비교적 넓은 $\mathrm{pH}$ 범위, 다양한 유기용매, 금속이온 및 계면활성 제에서 효소 안정성을 가진 것으로 확인되었고, 고정화 효소 인 Novozym과 비교하여도 효소 안정성에 손색이 없으므로 최적생산조건에 대한 추가적인 실험을 통해 효소안정성을 확 보한다면 환경 및 정밀화학 산업분야에 활용될 수 있을 것으 로 판단된다. 


\section{감사의 글}

본 연구는 한국연구재단 기본연구지원사업(과제번호: 20100009141)에 의해 지원되었으므로 이에 감사드립니다.

\section{References}

1. Aono, R., Itoh, M., Inoue, A. and Horikoshi, K. 1992. Isolation of novel toluene-tolerant strain Pseudomonas aeruginosa. Biosci Biotechnol Biochem 56, 145-146.

2. Dandavate, V., Jinjala, J., Keharia, H. and Madamwar, D. 2009. Production, partial purification and characterization of organic solvent tolerant lipase from Burkholderia multivorans V2 and its application for ester synthesis. Bioresour Technol 100, 3374-3381.

3. Fukuda, H., Kondo, A. and Noda, H. 2001. Biodisel fuel production by transesterificaion of oils. J Biosci Bioeng 92, 405-416

4. Ruchi, G., Anshu, G. and Khare, S. K. 2008. Lipase from solvent tolerant Pseudomonas aeruginosa strain: production optimization by response surface methodology and application. Bioresour Thehnol 99, 4796-4802.

5. Hasan, F., Shah, A. A. and Hameed, A. 2006. Industrial applications of microbial lipases. Enzyme Microb Technol 39, 235-251.

6. Jaeger, K. E. and Eggert, T. 2004. Enantioselective biocatalysis optimized by directed evolution. Curr Opin Chem Biol 15, 305-313.

7. Ji, Q., Xiao, S., He, B. and Liu, X. 2010. Purification and characterization of an organic solvent-tolerant lipase from Pseudomonas aeruginosa LK1 and its application of biodiesel production. J Mol catal B: Enzyme 66, 264-269.

8. Jose, C., Austic, G. B., Bonetto, R. D., Burton, R. M. and Briand, L. E. 2013. Investigation of the stability of Novozym (B) 435 in the production of biodiesel. Catalysis Today 213, 73-80.

9. Kwon, D. Y. and Rhee, J. S. 1986. A simple and rapid colorimetric method for determination of free fatty acid for lipase assay. J Am Oil Chem Soc 63, 89-92.

10. Laane, C. 1987. Medium engineering for bio-organic syn- thesis. Biocatal Biotransform 1, 17-22.

11. Magnusson, A. O., Rotticci-Mulder, J. C., Santagostino, A. and Hult, K. 2005. Creating space for large secondary alcohols by rational redesign of Candida antarctica lipase B. Chem Biochem 6, 1051-1056.

12. Ogino, H., Miyamoto, K. and Ishikawa, H. 1994. Organic solvent-tolerant bacterium which secretes an organic solvent-stable lipolytic enzyme. Appl Environ Microbiol 60, 38843886.

13. Ogino, H., Nakagawa, S., Shinya, K., Muto, T., Fujimura, N., Yasudo, N. and Ishikawa, H. 2000. Purification and characterization of organic solvent tolerant lipase from organic solvent tolerant Pseudomonas aeruginosa LST-03. J Biosci Bioeng 89, 451-457.

14. Rahman, R. N. Z. R. A., Baharum, S. N., Basri, M. and Salleh, A. B. 2005. High-yield purification of an organic solvent-tolerant lipase from Pseudomonas sp. strain S5. Anal Biochem 341, 267-274.

15. Chen, S., Qian, L. and Shi, B. 2007. Purification and properties of enantioselective lipase from a newly isolated Bacillus cereus C71. Process Biochem 42, 988-994.

16. Sharma, A. K., Tiwari, R. P. and Hoondal, G. S. 2001. Properties of a thermostable and solvent stable extracellular lipase from a Pseudomonas sp. AG-8. J Basic Microbiol 41, 363-366.

17. Sulong, M. R., Rahman, R. N. Z., Salleh, A. B. and Basri., M. 2006. A novel organic solvent tolerant lipase from Bacillus sphaericus 205y: Extracellular expression of a novel OST-lipase gene. Pro Exp Puri 49, 190-195.

18. Tanaka, D., Yoneda, S., Yamashiro, Y., Sakatoku, A., Kayashima, T., Yamakawa, K. and Nakamura, S. 2012. Characterization of a new cold-adapted lipase from Pseudomonas sp. TK-3. Appl Biochem Biotechnol 168, 327-338.

19. Winkler, U. K. and Stuckmann, M. 1979. Glycogen, hyaluronate, and some other polysaccharides greatly enhance the formation of exolipase by Serratua marcescens. J Bacteriol 138, 663-670.

20. Yoo, H. Y., Simkhada, J. R., Cho, S. S., Park, D. H., Kim, S. W., Seong, C. N. and Yoo, J. C. 2011. A novel alkaline lipase from Ralstonia with potential application in biodiesel production. Bioresour Technol 102, 6104-6111. 
초록 : Pseudomonas sp. BCNU 154 유래의 유기용매 내성 리파아제

최혜정 ${ }^{1}$ 황민정 ${ }^{1} \cdot$ 서정윤 $^{2} \cdot$ 주우홍 ${ }^{1}$ *

('창원대학교 생물학과·생물공학협동과정, ${ }^{2}$ 창원 대학교 환경공학과)

산업공단지역의 폐수에서 분리한 유기용매 내성 Pseudomanas sp. BCNU 154 리파아제의 최적조건은 $37^{\circ} \mathrm{C}, \mathrm{pH}$ 8 로 조사되었다. $\mathrm{BCNU} 154$ 의 crude 리파아제는 toluene에서 2시간 반응시 효소활성 약 $6.01 \mathrm{U} / \mathrm{ml}(117.53 \%)$ 로 가장 안정한 것으로 나타났다. 한편 $\mathrm{Ca}^{2+}, \mathrm{Mg}^{2+}, \mathrm{NH}_{4}{ }^{+}, \mathrm{Na}^{+}$이온 및 triton X-100은 효소를 활성화시킨 반면에 $\mathrm{Ba}^{2+}, \mathrm{Hg}^{2+}$ 및 $\mathrm{Zn}^{2+}$ 이온은 효소활성을 억제하였다. Pseudomonas sp. BCNU 154 리파아제는 상용 고정화 효소인 Novozym 435와 비교해서도 안정한 활성을 보였다. 그러므로 유기용매 내성 리파아제는 별도의 고정화 처리없이 도 화학산업공정에서 가능성 있는 whole cell 생물촉매로서 유용할 것으로 판단된다. 